\title{
Aplikasi Terapi Murottal Al-Quran Terhadap Tekanan Darah Pada Penderita Hipertensi Di Wilayah Kerja Puskesmas Nagrak Cianjur
}

\author{
Ega Apriliani ${ }^{*}$, Burhanuddin Basri ${ }^{2}$, Egi Mulyadi ${ }^{2}$ \\ ${ }^{1}$ Universitas Muhammadiyah Sukabumi \\ ${ }^{2}$ Universitas Muhammadiyah Sukabumi \\ ${ }^{3}$ Universitas Muhammadiyah Sukabumi
}

Email : ${ }^{1}$ egaapriliani0400@gmail.com, ${ }^{2}$ burhanuddun514@ummi.ac.id, ${ }^{3}$ egi.mulyadi2211@gmail.com

\begin{abstract}
Abstrak
Hipertensi adalah sebagai peningkatan tekanan darah sistolik sedikitnya $140 \mathrm{mmHg}$ atau tekanan diastolik sedikitnya $90 \mathrm{mmHg}$. Hipertensi Faktor resiko utama yang dapat menimbulkan terjadinya penyakit jantung, gagal jantung kongesif, stroke, gangguan penglihatan dan penyakit ginjal. Terapi murottal Al-Quran adalah terapi yang dapat mempercepat penurunan tekanan darah pada pasien penderita hipertensi. Tujuan: Diketahui pengaruh terapi murottal Al-Quran terhadap tekanan darah pada penderita hipertensi di wilayah kerja Puskesmas Nagrak Cianjur Hasil: Setelah diberikan terapi murottal Al-Quran satu kali sehari selama 7 hari berturut-turut di dapatkan hasil tekanan darah menurun yaitu dari 160/100 mmhg menjadi 155/100 $\mathrm{mmHg}$, pertemuan kedua dari $150 / 100 \mathrm{mmHg}$ menjadi $140 / 90 \mathrm{mmHg}$, pertemuan ketiga dan keempat dari 140/100 mmHg menjadi 130/90 $\mathrm{mmHg}$, pertemuan kelima dari 140/90 mmHg menjadi 130/90 $\mathrm{mmHg}$ dan pada pertemuan di hari keenam dan ketujuh dari 130/90 mmHg menjadi 120/90 mmHg. Kesimpulan: Adanya pengaruh terapi murottal Al-Quran terhadap tekanan darah pada penderita hipertensi.
\end{abstract}

Kata Kunci: Terapi Murottal Al-Quran, Tekanan Darah, Hipertensi

\begin{abstract}
Abstrack
Hypertension is an increase in systolic blood pressure of at least $140 \mathrm{mmHg}$ or diastolic pressure of at least $90 \mathrm{mmHg}$. Hypertension is the main risk factor that can lead to heart disease, congestive heart failure, stroke, visual impairment and kidney disease. Murottal Al-Quran therapy is a therapy that can accelerate the reduction of blood pressure in patients with hypertension. Objective: To find out the effect of Al-Quran murottal therapy on blood pressure in patients with hypertension in the working area of the Nagrak Cianjur Health Center. Results: After being given murottal Al-Quran therapy once a day for 7 consecutive days, the results of blood pressure decreased, namely from $160 / 100 \mathrm{mmHg}$ to $155 / 100 \mathrm{mmHg}$, the second meeting from $150 / 100 \mathrm{mmHg}$ to $140 / 90 \mathrm{mmHg}$, the third and fourth meetings from 140/100 $\mathrm{mmHg}$ to $130 / 90$ $\mathrm{mmHg}$, the fifth meeting from 140/90 $\mathrm{mmHg}$ to $130 / 90 \mathrm{mmHg}$ and at the on the sixth and seventh day from $130 / 90 \mathrm{mmHg}$ to $120 / 90 \mathrm{mmHg}$. Conclusion: The effect of murottal Al-Quran therapy on blood pressure in patients with hypertension.
\end{abstract}

Keywords: Al-Quran Murottal Therapy, Blood Pressure, Hypertension

\section{Pendahuluan}

Tekanan darah adalah daya yang diperlukan agar darah dapat mengalir di dalam pembuluh darah dan beredar mencapai seluruh jaringan tubuh manusia. Darah dengan lancar beredar ke seluruh bagian tubuh berfungsi sebagai media pengangkut oksigen serta zat lain yang di perlukan untuk kehidupan sel-sel di dalam tubuh (Alifariki, 2012).

Tekanan darah adalah suatu gaya yang diberikan darah terhadap dinding pembuluh darah dan ditimbulkan oleh desakan darah terhadap dinding arteri ketika darah tersebut dipompa dari jantung ke jaringan. Besar tekanan bervariasi tergantung pada pembuluh darah dan denyut jantung. Tekanan darah paling tinggi terjadi ketika ventrikel berkontraksi (tekanan sistolik) dan paling rendah ketika ventrikel berelaksasi (tekanan diastolik). (Nuraini, 2015) 
Hipertensi adalah sebagai peningkatan tekanan darah sistolik sedikitnya $140 \mathrm{mmHg}$ atau tekanan diastolik sedikitnya $90 \mathrm{mmHg}$. Hipertensi tidak hanya beresiko tinggi menderita penyakit jantung tetapi juga menderita penyakit lain seperti penyakit saraf ginjal dan pembuluh darah dan makin tinggi tekanan darah, makin besar resikonya. (Kusuma, 2015) Dari beberapa pendapat di atas, penulis menyimpulkan bahwa tekanan darah merupakan gaya yang diberikan darah terhadap dinding pembuluh darah dan ditimbulkan oleh desakan darah terhadap dinding arteri ketika darah tersebut dipompa dari jantung ke jaringan.

Menurut (Susanti et al., 2020), Penderita hipertensi diperkirakan mencapai 1 milyar di dunia, dan dua pertiga diantaranya berada di Negara berkembang. Angka tersebut kian hari kian mengkhawatirkan yaitu sebanyak 972 juta (26\%) orang dewasa di dunia menderita hipertensi. Angka ini terus meningkat tajam, dan diprediksi tahun 2025 sekitar $29 \%$ orang dewasa di seluruh dunia menderita hipertensi. (Susanti et al., 2020) (Riskesdas, 2018) menyatakan prevalensi hipertensi di Indonesia berdasarkan hasil pengukuran pada penduduk usia $\geq 18$ tahun sebesar 658. 201 dengan persentase $(34,11 \%)$, tertinggi dikalimantan Selatan (44.1\%), sedangkan terendah di Papua sebesar $(22,2 \%)$.

Prevalensi hipertensi berdasarkan diagnosis dokter atau minum obat antihipertensi, pada penduduk umur $\geq 18$ tahun menurut provinsi, (Riskesdas, 2018), provinsi Jawa Barat menunjukkan persentase 9,67\%, sedangkan yang terbesar ada di Provinsi DI Yogyakarta 10,68\%, yang terkecil ada di Provinsi Papua 4,39\% dengan rata-rata persentase $8,36 \%$. Dari sasaran strategis jangka menengah dinas kesehatan kabupaten Sukabumi tahun 2018 didapatkan, prevalensi tekanan darah tinggi pada kondisi akhir tahun 2018 menunjukkan persentase 24,28 (Dinkes Kabupaten Sukabumi, 2018). Dari rekapitulasi 10 besar penyakit di Puskesmas Nagrak Kabupaten Cianjur, 2020. Penyakit hipertensi berada di urutan ke enam, dengan jumlah total 2240, setelah Demam dengan jumlah 2289. (Profil Puskesmas Nagrak, 2020).

Hipertensi merupakan faktor resiko utama yang dapat menimbulkan terjadinya penyakit jantung, gagal jantung kongesif, stroke, gangguan penglihatan dan penyakit ginjal. Tekanan darah yang tinggi umumnya meningkatkan resiko terjadinya komplikasi tersebut. Hipertensi yang tidak diobati akan mempengaruhi semua sistem organ dan akhirnya memperpendek harapan hidup sebesar 10-20 tahun. Mortalitas pada pasien hipertensi lebih cepat apabila penyakitnya tidak terkontrol dan telah menimbulkan komplikasi ke beberapa organ vital. Sebab kematian yang sering terjadi adalah penyakit jantung dengan atau tanpa di sertai stroke dan gagal ginjal. (Nuraini, 2015)

Penatalaksanaan hipertensi antara lain pencegahan pada sasaran individu yang memiliki tekanan darah tinggi, riwayat keluarga hipertensi, dan satu atau lebih gaya hidup yang terkait dengan usia yang meningkatkan tekanan darah, seperti obesitas, asupan tinggi natrium, aktvitas fisik, dan asupan alkohol berlebihan; keputusan terapi untuk pasien hipertensi berdasarkan pada derajat peningkatan tekanan darah, keberadaan kerusakan organ sasaran, dan keberadaan penyakit kardiovaskuler klinis atau faktor risiko lain; modifikasi gaya hidup meliputi penurunan berat badan, olahraga, diet rendah garam, tingkatkan asupan kalium, dan magnesium, kurangi asupan alkohol, dan berhenti merokok.(Manuntung, 2018).

Penatalaksanaan pada pasien penderita hipertensi selain dengan farmakologi dapat juga dilakukan dengan non farmakologi seperti terapi komplementer terapi murottal Al-Quran. Tindakan untuk mengembalikan tekanan darah, adalah dengan terapi komplementer terapi murottal Al-Quran. Terapi komplementer adalah terapi yang dapat mempercepat penyembuhan dan penurunan tekanan darah pada pasien yang menderita hipertensi yaitu terapi murottal. Murottal adalah membaca Al-Quran dengan mempokuskan pada kebenaran bacaan dan lagu Al-Quran.(Harmawati \& Patricia, 2021).

Al-Quran merupaka suatu pengobatan non-farmakologi dengan menghilangkan stress dan meningkatkan kebahagiaan dalam hidup manusia. Indikator perubahan adalah menurunnya tingkat depresi, kecemasan, dan kesedihan dengan diakhiri adanya ketenangan jiwa sehingga mampu menangangkat berbagai macam penyakit. (Harmawati \& Patricia, 2021).Mekanisme murottal AlQuran dalam tubuh yaitu akan mengaktifkan gelombang fositif sebagai terapi relaksasi, hal ini akan menstimulasi adanya relaksasi yang dihasilkan oleh murottal Al-Quran. Saat otak diberikan stimulus 
berupa suara, dan suara berbanding lurus dengan frekwensi natural sel, maka sel akan bersonasi kemudian dapat aktif dan memberikan sinyal ke kelenjar. Selanjutnya tubuh akan mengeluarakan hormone endorphin, kondisi inilah yang akan menjadikan tubuh rileks maka akan terjadi penurunan epinephrine dan tekanan darah. (Harmawati \& Patricia, 2021).

Penelitian yang dilakukan oleh (Harmawati \& Patricia, 2021), dalam jurnal yang berjudul "Pengaruh Pemberian Terapi Murottal Surat Ar-Rahman Terhadap Tekanan Darah Pada Lansia Dengan Hipertensi Di Puskesmas Tanah Kampung", didapatkan hasil terdapat pengaruh terapi murottal Al-Quran surah Ar-Rahman terhadap tekanan darah pada penderita hipertensi, sistolik didapatkan nilai $\mathrm{p}$ value $=0,000(\mathrm{p} \leq 0,05)$, untuk sistolik dan $\mathrm{p}$ value $=0,000$ untuk diastolic.

Penelitian yang dilakukan oleh (Susilawati, 2019) dalam jurnal yang berjudul "Pengaruh Terapi Murottal Al-Qur'an Surah Ar-Rahman terhadap Penurunan Tekanan Darah pada Lansia Penderita Hipertensi di PSTW Budi Luhur Kota Jambi”, didapatkan hasil terdapat pengaruh terapi murottal AlQur'an surah Ar-Rahman terhadap penurunan tekanan darah pada penderita hipertensi di PSTW Budi Luhur Kota Jambi. Hasil uji analisis t- test pada tekanan darah sistol didapatkan p-value $0,000<(0,05)$ dan hasil t-test pada tekanan darah diastol adalah $0,000<(0,05)$

Penelitian yang dilakukan oleh (Parman et al., 2020), dalam jurnal yang berjudul "Pengaruh Terapi Murattal Surah Ar-Rahman Terhadap Tekanan Darah Lansia Penderita Hipertensi Di Puskesmas Simpang Kawat Kota Jambi Tahun 2018", didapatkan hasil bahwa adanya pengaruh tekanan darah sebelum dan setelah pemberian terapi murottal Al-Quran surah Ar-Rahman pada penderita hipertensi di Puskesmas Simpang Kawat Kota Jambi (p-value $=0.000)$ dan ada perbedaan sebelum dan sesudah pemberian terapi murottal Al-Quran surat Ar-Rahman terhadap perubahan tekanan darah diastol pada pasien hipertensi ( $\mathrm{p}$-value $=0.000$ ). Berdasarkan uraian di atas maka peneliti tertarik untuk melakukan “Aplikasi Terapi Murottal Al-Quran Terhadap Tekanan Darah Pada Penderita Hipertensi Di Wilayah Kerja Puskesmas Nagrak Cianjur".

\section{Metode Penelitian}

Dalam Karya Tulis Ilmiah ini, penulis menggunakan metode pengumpulan data sebagai berikut:

1. Observasi Pengamatan

Dalam penelitian ini peneliti melakukan pemeriksaan fisik dengan pendekatan IPPA: Insfeksi, Palpasi, Perkusi, Auskultasi pada sistem tubuh klien. Peneliti juga menggunakan metode pengumpulan data observasi yang meninjau langsung keadaan responden. Dalam hal ini peneliti dapat mengetahui kondisi, tempat tinggal, status kesehatan dan keadaan psikologis responden.

2. Wawancara

Dalam metode ini peneliti melakukan anamnesis dengan fokus pertanyaan: pengkajian identitas pasien, keluhan utama, riwayat kesehatan sekarang, riwayat kesehatan dahulu, riwayat kesehatan keluarga, serta pola aktivitas sehari-hari dan lain-lain.

3. Studi Pustaka

Penulis memperoleh sumber-sumber kepustakaan melalui jurnal, buku, internet, yang memiliki hubungan dengan konsep dan teori yang terkait dengan hipertensi dan aplikasi terapi murottal Al-Quran.

\section{Hasil Penelitian}

1. Pengkajian

\section{a. Data Umum}

Dalam laporan ini penulis mendapatkan data klien dengan Hipertensi. Klien bernama inisial TN. N berumur 45 tahun beralamatkan di Kp. Wargaluyu, Rt/Rw 01/11, des. Nagrak, Cianjur. Klien beragama Islam, bekerja sebagai Wiraswasta. 


\section{b. Pengkajian 13 Domain NANDA}

Pada domain pertama Health Promotion, Pada riwayat kesehatan klien, keluhan utama yang dirasakan klien adalah nyeri pada kepala, dan pada riwayat penyakit sekarang, didapatkan hasil pengkajian yaitu klien mengeluh nyeri di bagian kepala sebelah kanan, nyeri dirasakan seperti di tusuk-tusuk dan terkadang nyeri dirasakan ketika terbangun dari tidur dan nyeri terasa semakin berat ketika berjalan. Klien juga mengatakan pernah mengalami penyakit serupa di masa lalu. Pada riwayat kesehatan keluarga, klien mengatakan tinggal bersama istrinya dan dua orang putrinya, klien mengatakan di dalam keluarganya tidak ada yang mempunyai penyakit yang serupa. Kemampuan mengontrol kesehatan keluarga baik, jika terdapat keluhan kesehatan pada anggota keluarga, keluarga langsung periksa ke klinik, puskesmas atau rumah sakit. Pola hidup TN. N yaitu berolahraga seminggu sekali setiap hari minggu dan aktivitas lainnya adalah bekerja.

Pada domain kedua yaitu Nutrition, klien mengatakan tahu tentang nutrisi bagi penderita hipertensi, berat badan terakhir klien adalah $80 \mathrm{~kg}$ dengan tinggi badan klien adalah $168 \mathrm{~cm}$. Turgor kulit normal. Nafsu makan klien baik, makan 3x sehari, jenis makanan yang dikonsumsi nasi, sayuran, dan terkadang makan buah-buahan, klien mengatakan mengkonsumsi makanan dengan diet rendah garam. Klien dapat beraktivitas dengan baik dan mandiri. Untuk pola asupan cairan klien yaitu klien minum air putih \pm 2 liter/hari. Pada pemeriksaan abdomen klien tidak ada kelainan atau masalah, tidak ada luka, tidak ada nyeri tekan dan bising usus 14 $\mathrm{x} / \mathrm{menit}$.

Pada pengkajian domain ketiga yaitu Elimination, urin klien normal 6x sehari, klien tidak ada rasa ketidaknyamanan pada pola pembuangan urine. Klien tidak ada riwayat kelainan kandung kemih, klien mengatakan urine berwarna kuning bening, dengan bau khas. Pada eliminasi gastrointestinal pola eliminasi klien BAB $2 x$ sehari, klien juga tidak ada masalah pada pola eliminasi gastrointestinal, tidak ada konstipasi. Di sistem integumen integritas kulit normal dan tidak terdapat udem.

Domain ke empat Activity/Rest, waktu istirahat klien 8 jam/hari, klien jarang mengalami insomnia, klien berolahraga 1x/minggu dan klien bekerja setiap hari. Bantuan ADL klien minimal dengan makan sendiri, toileting mandiri, kebersihan klien mandiri, klien berpakaian mandiri, kekuatan otot ekstremitas kaki dan tangan 5. Klien tidak mempunyai riwayat penyakit jantung, tidak ada edema ekstremitas kaki dan tangan. Tekanan darah 160/100 mmHg. Tekanan vena jugularis teraba. Pada pemeriksaan jantung inspeksi tidak ada luka, ictus cordis tidak tampak, palpasi tidak ada cardiomegali, tidak ada nyeri, perkusi pekak, auskultasi reguler. Pemeriksaan Pulmonary Respon didapatkan klien tidak ada penyakit sistem pernafasan, tidak ada gangguan pernafasan dan inspeksi paru-paru tidak ada luka, ekspansi dada merata, RR 24x/menit, palpasi tidak ada nyeri tekan, tidak ada krepitasi, perkusi sonor, auskultasi paruparu vesikuler.

Pada domain kelima Perception/Cognition, tingkat pendidikan terakhir klien SMP, pengetahuan tentang penyakitnya cukup, dan orientasi klien terhadap waktu, dan tempat, baik. Klien memiliki riwayat nyeri kepala. Komunikasi klien menggunakan bahasa Sunda serta klien tidak ada kesulitan dalam berkomunikasi.

Pada domain keenam Self Perception, klien mengatakan tidak mengalami cemas yang berarti, klien tidak ada perasaan putus asa, klien tidak merasakan cemas dengan penyakitnya dan dapat dukungan dari istri dan anak-anaknya sehingga klien optimis bahwa penyakitnya akan segera sembuh.

Pada domain ke tujuh Role Relationship, status hubungan klien yaitu menikah. Perubahan hidup klien selama sakit yaitu klien tidak bisa makan terlalu banyak dan beraktivitas terlalu berat. Interaksi dengan keluarga, tetangga dan masyarakat baik.

Pada domain kedelapan Sexuality, klien mempunyai 2 anak yaitu anak pertama adalah perempuan, dan anak yang kedua yaitu perempuan, klien tidak mempunyai masalah/disfungsi seksual. 
Pada domain kesembilan Coping/Stres Tolerance, klien mengatakan tidak merasakan cemas yang berarti karena dapat dukungan dari istri dan anak jika penyakitnya dapat segera sembuh, kemampuan mengatasi rasa tersebut baik karena selalu didukung oleh istri dan anaknya.

Pada domain ke sepuluh Life Principles, nilai kepercayaan klien jarang selalu mengikuti kegiatan keagamaan seperti mengikuti pengajian 2x/minggu. Kemampuan untuk berpartisipasi klien baik. Kemampuan memecahkan masalah baik, saat memecahkan masalah selalu dimusyawarahkan dengan keluarga.

Pada domain ke sebelas Safety/Protection, klien tidak memiliki alergi obat maupun makanan. Klien tidak mempunyai penyakit autoimun. Tidak terdapat gangguan termoregulasi, tidak ada gangguan atau resiko komplikasi immobilisasi.

Pada domain kedua belas Comfort, klien mengatakan ada nyeri yang berarti nyeri diakibatkan dari meningkatnya tekanan darah.

Pada domain ketiga belas Growth/Development, pertumbuhan dan perkembangan klien baik.

2. Analisa Data

Analisa data pada tanggal 22 Mei 2021 pukul 08.15 WIB didapatkan data subyektif klien mengatakan nyeri pada kepala, nyeri pada skala 4 (0-10), dan klien mengatakan nyeri dirasakan seperti di tusuk-tusuk. Data obyektifnya didapatkan tekanan darah: 160/100 mmHg, nadi: 98x/menit, respirasi $24 \mathrm{x} /$ menit dan suhu: $37^{\circ}$ Celcius, klien tampak memegang bagian kepala yang terasa nyeri.

3. Diagnosa Keperawatan

Hasil pengkajian pada TN. N didapatkan prioritas diagnosa keperawatan yaitu: Nyeri akut berhubungan dengan peningkatan tekanan vaskuler serebral dan iskemia.

4. Intervensi Keperawatan

Penulis membuat rencana keperawatan dengan tujuan setelah dilakukan tindakan keperawatan terapi murottal Al-Quran selama 7 hari (satu kali sehari), diharapkan masalah keperawatan yang muncul dapat teratasi:

3.4.1 Nyeri akut berhubungan dengan peningkatan tekanan vaskuler serebral dan iskemia

Nyeri akut berhubungan dengan peningkatan tekanan vaskuler serebral dan iskemia dapat teratasi dengan kriteria hasil kemampuan menggunakan teknik Non-farmakologis meningkat, tekanan darah sistolik membaik dan tekanan darah diastolik membaik, mampu mengontrol nyeri (tahu penyebab nyeri, mampu menggunakan tehnik Non-farmakologis untuk mengurangi nyeri, mencari bantuan), mampu mengenali nyeri (Skala, intensitas, frekuensi, dan tanda nyeri), menyatakan rasa nyaman setelah nyeri berkurang. Tindakan yang dilakukan adalah Monitor TTV sebelum dan sesudah diberikan terapi murottal Al-Quran, Lakukan pengkajian nyeri secara komperehensif termasuk lokasi, karakteristik, durasi, frekuensi, kualitas dan factor presipitasi, ajarkan tentang teknik non-farmakologiss untuk mengurangi rasa nyeri (teknik relaksasi nafas dalam), Berikan teknik non-farmakologis dengan terapi Murottal Al-Quran surah Ar-Rahman selama \pm 15 menit.

5. Implementasi Keperawatan

Implementasi pada pertemuan pertama tanggal 22 Mei 2021, pukul 08.15 WIB dengan masalah keperawatan nyeri akut berhubungan dengan peningkatan tekanan vaskuler serebral dan iskemia yaitu, memonitor tanda-tanda vital klien seperti mengukur tekanan darah sebelum dan sesudah diberikan terapi murottal Al-Quran, memonitor nadi, respirasi dan suhu, melakukan pengkajian nyeri secara komperehensif termasuk lokasi, karakteristik, durasi, frekuensi, kualitas dan faktor presipitasi, mengajarkan tentang teknik non-farmakologiss untuk mengurangi rasa nyeri (teknik relaksasi nafas dalam), Berikan teknik non-farmakologis dengan terapi Murottal AlQuran surah Ar-Rahman selama \pm 15 menit.e

Implementasi pada pertemuan kedua tanggal 23 Mei 2021, pukul 08.20 WIB dengan masalah keperawatan nyeri akut berhubungan dengan peningkatan tekanan vaskuler serebral dan iskemia 
yaitu, memonitor tekanan darah klien sebelum dan sesudah diberikan terapi murottal Al-Quran, mengajarkan teknik non-farmakologiss untuk mengurangi rasa nyeri (Teknik relaksasi nafas dalam), memberikan teknik non-farmakologis dengan terapi Murottal Al-Quran surah ArRahman selama \pm 15 menit.

Implementasi pada pertemuan ketiga tanggal 24 Mei 2021, pukul 08.09 WIB dengan masalah keperawatan nyeri akut berhubungan dengan peningkatan tekanan vaskuler serebral dan iskemia yaitu, memonitor tekanan darah sebelum dan sesudah diberikan terapi murottal Al-Quran, mengajarkan teknik non-farmakologiss untuk mengurangi rasa nyeri (Teknik relaksasi nafas dalam), memberikan teknik non-farmakologis dengan terapi Murottal Al-Quran surah ArRahman selama \pm 15 menit.

Implementasi pada pertemuan keempat tanggal 25 Mei 2021, pukul 08.27 WIB dengan masalah keperawatan nyeri akut berhubungan dengan peningkatan tekanan vaskuler serebral dan iskemia yaitu, memonitor tekanan darah sebelum dan sesudah diberikan terapi murottal AlQuran, mengajarkan teknik non-farmakologiss untuk mengurangi rasa nyeri (Teknik relaksasi nafas dalam), memberikan teknik non-farmakologis dengan terapi Murottal Al-Quran surah ArRahman selama \pm 15 menit.

Implementasi pada pertemuan kelima tanggal 26 Mei 2021, pukul 08.55 WIB dengan masalah keperawatan nyeri akut berhubungan dengan peningkatan tekanan vaskuler serebral dan iskemia yaitu, memonitor tekanan darah sebelum dan sesudah diberikan terapi murottal AlQuran, mengajarkan teknik non-farmakologiss untuk mengurangi rasa nyeri (Teknik relaksasi nafas dalam), memberikan teknik non-farmakologis dengan terapi Murottal Al-Quran surah ArRahman selama \pm 15 menit.

Implementasi pada pertemuan keenam tanggal 27 Mei 2021, pukul 09.01 WIB dengan masalah keperawatan nyeri akut berhubungan dengan peningkatan tekanan vaskuler serebral dan iskemia yaitu, memonitor tekanan darah sebelum dan sesudah diberikan terapi murottal AlQuran, mengajarkan teknik non-farmakologiss untuk mengurangi rasa nyeri (Teknik relaksasi nafas dalam), memberikan teknik non-farmakologis dengan terapi Murottal Al-Quran surah ArRahman selama \pm 15 menit.

Implementasi pada pertemuan ketujuh tanggal 28 Mei 2021, pukul 08.44 WIB dengan masalah keperawatan nyeri akut berhubungan dengan peningkatan tekanan vaskuler serebral dan iskemia yaitu, memonitor tekanan darah sebelum dan sesudah diberikan terapi murottal AlQuran, mengajarkan teknik non-farmakologiss untuk mengurangi rasa nyeri (Teknik relaksasi nafas dalam), memberikan teknik non-farmakologis dengan terapi Murottal Al-Quran surah ArRahman selama \pm 15 menit.

\section{Evaluasi Keperawatan}

Tindakan keperawatan yang telah dilakukan selama 7 hari (satu kali sehari dilakukan tindakan keperawatan) tanggal 22 Mei 2021-28 Mei 2021, dihasilkan evaluasi keperawatan:

Evaluasi keperawatan pada pertemuan pertama tanggal 22 Mei 2021, pukul 08. 32 WIB dengan masalah keperawatan nyeri akut berhubungan dengan peningkatan tekanan vaskuler serebral dan iskemia yaitu didapatkan hasil tekanan darah sebelum diberikan terapi murottal AlQuran 160/100 mmHg dan setelah diberikan terapi murottal Al-Quran 155/100, skala nyeri 4, nadi: 98x/menit, respirasi $24 \mathrm{x} /$ menit dan suhu: $37^{\circ}$ Celcius, klien mengatakan nyeri semakin terasa berat ketika berjalan, nyeri dirasakan di kepala sebelah kanan dan klien mengatakan nyeri berkurang ketika mengkonsumsi obat antihipertensi (Amlodipin $10 \mathrm{ml}$ ) yang dimiliki klien. Klien merasa rileks setelah diberikan terapi murottal Al-Quran, klien mengatakan nyeri sedikit berkurang setelah diberikan terapi murottal Al-Quran, skala nyeri 3, klien terlihat nyaman dan tenang ketika diberikan terapi murottal Al-Quran dan klien merasa senang ketika diberikan terapi murottal Al-Quran.

Evaluasi keperawatan pada pertemuan kedua tanggal 23 Mei 2021, pukul 08. 38 WIB dengan masalah keperawatan nyeri akut berhubungan dengan peningkatan tekanan vaskuler serebral dan iskemia yaitu, didapatkan hasil tekanan darah sebelum diberikan terapi murottal Al-Quran 
150/100 mmHg dan setelah diberikan terapi murottal Al-Quran 140/90, skala 3, klien mengatakan nyeri pada kepala berkurang, klien mengatakan ketika diberikan terapi murottal Al-Quran terasa rileks dan mengantuk, dan klien nampak tenang dan senang ketika diberikan terapi murottal AlQuran.

Evaluasi keperawatan pada pertemuan ketiga tanggal 24 Mei 2021, pukul 08. 23 WIB dengan masalah keperawatan nyeri akut berhubungan dengan peningkatan tekanan vaskuler serebral dan iskemia yaitu, didapatkan hasil tekanan darah sebelum diberikan terapi murottal Al-Quran 140/100 mmHg dan setelah diberikan terapi murottal Al-Quran 130/90 mmHg, skala 2, klien mengatakan merasa lebih baik sesudah diberikan terapi murottal Al- Quran, klien mengatakan nyeri kepala berkurang, klien tampak tenang ketika di berikan dan sesudah di berikan terapi murottal Al-Quran.

Evaluasi keperawatan pada pertemuan keempat tanggal 25 Mei 2021, pukul 08. 43 WIB dengan masalah keperawatan nyeri akut berhubungan dengan peningkatan tekanan vaskuler serebral dan iskemia yaitu, didapatkan hasil tekanan darah sebelum diberikan terapi murottal AlQuran 140/100 mmHg, skala 2, dan setelah diberikan terapi murottal Al-Quran 130/90 mmHg, klien mengatakan nyeri pada kepala berkurang, dan ketika diberikan terapi murottal Al-Quran klien mengatakan merasa sangat lebih baik dan klien Nampak senang.

Evaluasi keperawatan pada pertemuan kelima tanggal 26 Mei 2021, pukul 09. 11 WIB dengan masalah keperawatan nyeri akut berhubungan dengan peningkatan tekanan vaskuler serebral dan iskemia, didapatkan hasil tekanan darah sebelum diberikan terapi murottal Al-Quran 140/90 $\mathrm{mmHg}$, skala 1, dan setelah diberikan terapi murottal Al-Quran 130/90 mmHg, klien mengatakan semakin sering diberikan terapi semakin membaik, hamper tidak terasa nyeri pada kepala dan klien terlihat senang dan bersyukur dengan mengucapkan alhamdulillah.

Evaluasi keperawatan pada pertemuan keenam tanggal 27 Mei 2021, pukul 09. 19 WIB dengan masalah keperawatan nyeri akut berhubungan dengan agen pencedera biologis ditandai dengan mengeluh nyeri, dan tekanan darah meningkat yaitu, didapatkan hasil tekanan darah sebelum diberikan terapi murottal Al-Quran 130/90 $\mathrm{mmHg}$, skala 0, dan setelah diberikan terapi murottal Al-Quran 120/90 mmHg, klien mengatakan merasa senang dengan tekanan darahnya yang semakin hari semakin membaik, klien nampak nyaman dan rileks ketika diberikan terapi murottal Al-Quran.

Evaluasi keperawatan pada pertemuan ketujuh tanggal 28 Mei 2021, pukul 08. 15 WIB dengan masalah keperawatan nyeri akut berhubungan dengan agen pencedera biologis ditandai dengan mengeluh nyeri, dan tekanan darah meningkat yaitu, didapatkan hasil tekanan darah sebelum diberikan terapi murottal Al-Quran 130/90 $\mathrm{mmHg}$ dan setelah diberikan terapi murottal Al-Quran 120/90 mmHg, skala 0, klien mengatakan sangat senang dengan diberikannya terapi Al-Quran, klien mengatakan akan mempraktekan terapi murottal Al-Quran secara mandiri, klien nampak senang dan tenang setelah mengetahui tekanan darahnya semakin hari semakin membaik.

\section{Pembahasan}

1. Pengkajian

Keluhan utama yang dirasakan klien hipertensi adalah nyeri kepala. Berdasarkan pada pengkajian riwayat kesehatan sekarang pada tanggal 22 mei 2021, klien mengeluh nyeri pada kepala, dan pada riwayat penyakit sekarang, didapatkan hasil pengkajian yaitu klien mengeluh nyeri di bagian kepala sebelah kanan, nyeri dirasakan seperti di tusuk-tusuk dan terkadang nyeri dirasakan ketika terbangun dari tidur dan nyeri terasa semakin berat ketika berjalan. Klien juga mengatakan pernah mengalami penyakit serupa di masa lalu. Pada riwayat kesehatan keluarga, klien mengatakan tinggal bersama istrinya dan dua orang putrinya, klien mengatakan di dalam keluarganya tidak ada yang mempunyai penyakit yang serupa. Kemampuan mengontrol kesehatan keluarga baik, jika terdapat keluhan kesehatan pada anggota keluarga, keluarga langsung periksa ke klinik atau rumah sakit. Pola hidup TN. N yaitu berolahraga seminggu sekali setiap hari minggu dan aktivitas lainnya adalah bekerja dan pada pemeriksaan 13 domain, 
terdapat nyeri pada kepala, nyeri pada skala 4, dan klien mengatakan nyeri dirasakan seperti di tusuk-tusuk. Tekanan darah: 160/100 $\mathrm{mmHg}$, nadi: 98x/menit, respirasi $24 \mathrm{x} / \mathrm{menit}$ dan suhu: $37^{\circ}$ Celcius.

Hal ini sesuai dengan teori menurut NANDA (Kusuma, 2015) yang menyatakan bahwa keluhan pada pasien hipertensi adalah nyeri akut berhubungan dengan peningkatan tekanan vaskuler serebral dan iskemia. Dari uraian diatas, tidak ada kesenjangan antara teori dan kasus.

2. Diagnosa Keperawatan

Hasil penelitian didapatkan diagnosa keperawatan yang muncul adalah nyeri akut berhubungan dengan peningkatan tekanan vaskuler serebral dan iskemia.

Hal ini sesuai dengan teori NANDA (Kusuma, 2015). Bahwa diagnosa keperawatan yang muncul pada pasien hipertensi adalah: Penurunan curah jantung berhubungan dengan peningkatan afterload vasokonstriksi, hipertrofi atau rigiditas ventrikuler, iskemia miokard. Nyeri akut berhubungan dengan peningkatan tekanan vaskuler serebral dan iskemia. Kelebihan volume cairan. Intoleransi aktivitas berhubungan dengan kelemahan ketidakseimbangan suplai dan kebutuhan oksigen. Ketidakefektipan koping. Resiko ketidakefektipan perfusi jaringan otak. Resiko cidera. Defisiensi pengetahan, dan Ansietas.

Pada diagnosa, penulis hanya mengambil satu prioritas diagnosa keperawatan yaitu nyeri akut berhubungan dengan peningkatan tekanan vaskuler serebral dan iskemia, hal ini karena penulis ingin lebih memfokuskan pengaplikasian terapi murottal Al-Quran terhadap penurunan tekanan darah.

3. Intervensi Keperawatan

Intervensi yang dilakukan pada diagnosa nyeri akut berhubungan dengan peningkatan tekanan vaskuler serebral dan iskemia, yaitu: Monitor TTV sebelum dan sesudah diberikan terapi murottal Al-Quran, Lakukan pengkajian nyeri secara komperehensif termasuk lokasi, karakteristik, durasi, frekuensi, kualitas dan factor presipitasi, ajarkan tentang teknik nonfarmakologis untuk mengurangi rasa nyeri (teknik relaksasi nafas dalam), Berikan teknik nonfarmakologi dengan terapi Murottal Al-Quran surah Ar-Rahman selama \pm 15 menit.

Intervensi diatas sesuai dengan teori NANDA (Kusuma, 2015), yaitu Monitor TTV, Lakukan pengkajian nyeri secara komperehensif termasuk lokasi, karakteristik, durasi, frekuensi, kualitas dan factor presipitasi, ajarkan tentang teknik non-farmakologis, berikan teknik non-farmakologi, dan tidak ada kesenjangan antara intervensi yang diberikan peneliti dengan intervensi yang dilakukan pada jurnal (Harmawati \& Patricia, 2021), yaitu diberikan intervensi non-farmakologi dengan terapi murottal Al-Quran.

Terapi murottal Al-Quran ini adalah sebagai intervensi tambahan untuk melengkapi intervensi NANDA, dan terapi murottal Al-Quran ini adalah sebagai terapi alternativ untuk menurunkan tekanan darah pada hipertensi.

4. Implementasi

Implementasi yang dilakukan penulis pada nyeri akut berhubungan dengan peningkatan tekanan vaskuler serebral dan iskemia, mulai dari tanggal 22-28 Mei 2021 dengan memonitor tanda-tanda vital klien seperti mengukur tekanan darah sebelum dan sesudah diberikan terapi murottal Al-Quran, memonitor nadi, respirasi dan suhu, melakukan pengkajian nyeri secara komperehensif termasuk lokasi, karakteristik, durasi, frekuensi, kualitas dan factor presipitasi, mengajarkan tentang teknik non-farmakologis untuk mengurangi rasa nyeri (teknik relaksasi nafas dalam), berikan teknik non-farmakologi dengan terapi murottal Al-Quran surah Ar-Rahman selama \pm 15 menit.

Implementasi yang penulis lakukan adalah aplikasi terapi murottal Al-Quran, hal ini tidak terdapat kesenjangan antara konsep teoritis dengan pembahasan pada kasus TN. N, karna penulis mengacu pada teori yang ada dan standar operasional yang telah dibuat, dimana tindakan yang dilakukan pada TN. N sesuai dengan kondisinya.

Terapi murottal Al-Quran ini adalah sebagai implementasi tambahan untuk melengkapi implementasi NANDA, dan terapi murottal Al-Quran ini adalah sebagai terapi alternative untuk 
menurunkan tekanan darah pada hipertensi.

5. Evaluasi

Dalam proses evaluasi penulis menggunakan SOAP dalam mengevaluasi klien, setelah melakukan terapi murottal Al-Quran klien terlihat lebih rileks dan terlihat tenang saat diberikan terapi murottal Al-Quran, dan adanya perubahan pada tekanan darah setelah diberikan terapi murottal Al-Quran, sebagaimana sesuai dengan pendapat (Nurhayati, Abdul Halim, 2020) bahwa Terdapat pengaruh yang signifikan antara terapi murottal Al-Qur'an terhadap penurunan tekanan darah pada penderita hipertensi di ruang Cempaka RSUD H. Soewondo Kendal ( $p$ value $=0,00$ $<\alpha=0,05$.

Pada saat dilakukan evaluasi akhir yaitu pada tanggal 28 Mei 2021 yaitu didapatkan hasil bahwa terdapat penurunan tekanan darah setelah dilakukan intervensi terapi murottal Al-Quran satu kali sehari selama 7 hari berturut-turut. Hal ini membuktikan bahwa ada pengaruh dalam pemberian terapi murottal Al-Quran terhadap penurunan tekanan darah pada hipertensi, hal tersebut sesuai dengan penelitian (Harmawati \& Patricia, 2021) bahwa terapi murottal Al-Quran dapat berpengaruh terhadap tekanan darah pada hipertensi. Selain itu klien juga dapat mengimplementasikan terapi murottal Al-Quran, hal ini sesuai dengan tujuan yang diharapkan pada saat perumusan intervensi. Dengan demikian tidak ditemukan kesenjangan dalam tahap evaluasi ini dengan teori yang ada.

\section{Simpulan}

1. Pengkajian

Hasil pengkajian pada TN. N telah disimpulkan, berdasarkan teori dan konsepnya dapat disimpulkan klien mengeluh nyeri di bagian kepala sebelah kanan dan melakukan pengkajian dengan cara observasi, wawancara dan pemeriksaan fisik. Dengan pengkajian 13 Domain Nanda.

2. Diagnosa Keperawatan

Diagnosa prioritas yang ditegakkan pada TN. N adalah nyeri akut berhubungan dengan peningkatan tekanan vaskuler serebral dan iskemia.

3. Intervensi

Intervensi yang telah diberikan penulis mengacu pada beberapa teori dan hasil penelitian. Rencana yang diberikan antara lain monitor TTV sebelum dan sesudah diberikan terapi murottal Al-Quran, Lakukan pengkajian nyeri secara komperehensif termasuk lokasi, karakteristik, durasi, frekuensi, kualitas dan factor presipitasi, ajarkan tentang teknik non-farmakologis untuk mengurangi rasa nyeri (teknik relaksasi nafas dalam), berikan teknik non-farmakologi dengan terapi Murottal Al-Quran surah Ar-Rahman selama \pm 15 menit.

4. Implementasi

Implementasi yang dilakukan selama 7 hari, dilakukan 7 kali pertemuan untuk melakukan aplikasi terapi murottal Al-Quran terhadap tekanan darah pada hipertensi.

5. Evaluasi

Evaluasi untuk diagnosa prioritas nyeri akut berhubungan dengan peningkatan tekanan vaskuler serebral dan iskemia. Setelah diberikan implementasi selama 7 hari yang dilakukan 7 kali pertemuan masalah teratasi dengan hasil karakteristik tekanan darah menurun, dalam pertemuan hari pertama, sedikit terjadi penurunan tekanan darah yaitu dari 160/100 mmhg menjadi 155/100 $\mathrm{mmHg}$, dengan skala 4 menjadi 3, pertemuan kedua dari 150/100 $\mathrm{mmHg}$ menjadi 140/90 mmHg, dengan skala 3, pertemuan ketiga dan keempat didapatkan hasil tekanan darah yang menetap yaitu dari $140 / 100 \mathrm{mmHg}$ menjadi $130 / 90 \mathrm{mmHg}$, dengan skala 2, pertemuan kelima dari 140/90 mmHg menjadi 130/90 $\mathrm{mmHg}$, dengan skala 1 dan pada pertemuan di hari keenam dan ketujuh didapatkan hasil penurunan tekanan darah yang menetap yaitu dari 130/90 mmHg menjadi $120 / 90 \mathrm{mmHg}$, dengan skala 0 . 


\section{Referensi}

Alifariki, L. $\quad$ O. (2012). $\quad$ Epidemiologi Hipertensi. https://books.google.co.id/books?id=PISqDwAAQBAJ\&pg=PA3\&dq=Moniaga+2012+Tekana $\mathrm{n}+$ Darah\&hl=id\&sa=X\&ved=2ahUKEwjRqZTEupnwAhWZWisKHePyC8gQ6wEwAHoECA EQBQ\#v=onepage\&q=Moniaga 2012 Tekanan Darah\&f=false

Atmojo, J. T., Putra, M. M., Astriani, N. M. D. Y., Dewi, P. I. S., \& Bintoro, T. (2019). Efektifitas Terapi Relaksasi Benson Terhadap Tekanan Darah Pada Penderita Hipertensi. Interest : Jurnal Ilmu Kesehatan, 8(1), 51-60. https://doi.org/10.37341/interest.v8i1.117

Ayunda, T. (2019). Penerapan Pelaksanaan Asuhan Keperawatan Pada Pasien Hipertensi. https://doi.org/10.31219/osf.io/t8y3b

Aziz Alimul Hidayat. (2021). Keperawatan Dasar 1. Health Books Publishing. https://www.google.co.id/books/edition/Keperawatan_Dasar_1_Untuk_Pendidikan_Ner/TRYf EAAAQBAJ?hl=id\&gbpv=1\&dq=buku+keperawatan+cara+pengukuran+tekanan+darah\&pg= PA65\&printsec $=$ frontcover

Burhanuddin Basri, T. U. dan E. M. (2020). Konsep Dasar Dokumentasi Keperawatan. Media Sains Indonesia.

https://www.google.co.id/books/edition/Konsep_Dasar_Dokumentasi_Keperawatan/uiwNEAA AQBAJ?hl=id\&gbpv=1\&dq=konsep+dasar+dokumentasi+keperawatan\&printsec=frontcover

Dinkes Kabupaten Sukabumi. (2018). Dinas Kesehatan Kabupaten Sukabumi Tahun 2018.

Fikriana, R. (2018). Sistem Kardiovaskuler. DEEPULISH. https://www.google.co.id/books/edition/Sistem_Kardiovaskuler/Rm9nDwAAQBAJ?hl=id\&gb $\mathrm{pv}=1 \& \mathrm{dq}=$ gangguan + sistem + kardiovaskuler \&printsec $=$ frontcover

Harmawati, S. H., \& Patricia, H. (2021). Pengaruh Pemberian Terapi Murottal Surat Ar-Rahman Terhadap Tekanan Darah Pada Lansia Dengan Hipertensi Di Puskesmas Tanah Kampung. Prosiding Seminar Nasional STIKES Syedza Saintika, 1(1), 515-527.

Istichomah. (2021). Modul Praktikum Keperawatan II. Media Sains Indonesia. https://www.google.co.id/books/edition/Modul_Praktikum_Keperawatan_Dasar_II/klkjEAAA QBAJ?hl=id\&gbpv=1\&dq=Pengkajian+adalah+pemikiran+dasar+dari+proses+keperawatan+y ang+bertujuan+untuk+mengumpulkan+informasi+atau+data+tentang+pasien,+agar+dapat+me ngidentif

Kusuma, A. H. N. dan H. (2015). Aplikasi Asuhan Berdasarkan Diagnosa Medis \& Nanda NIC-NOC. Mediaction Jogja.

Manuntung, N. A. (2018). Terapi Perilaku Kognitif Pada Pasien Hipertensi. Wineka Media. https://books.google.co.id/books?id=VWGIDwAAQBAJ\&pg=PA21\&dq=Penatalaksanaan+hip ertensi\&hl=id\&sa $=$ X\&ved $=2$ ahUKEwjZu4kyZnwAhU47HMBHWyYBscQ6wEwAnoECAMQBQ\#v=onepage\&q=Penatalaksanaan hipertensi\&f=false 
Nuraini, B. (2015). Risk Factors of Hypertension. J Majority, 4(5), 10-19.

Nurhayati, Abdul Halim, dan H. T. (2020). “Penerapan Terapi Murotal Al - Qur ' an Pada Lansia Yang Mengalami Hipertensi terhadap Tekanan Darah " Di Lks Al-Akhsan Hajimena Natar Lampung Selatan Provinsi Lampung Tahun 2020. ANDASIH Jurnal Pengabdian Kepada Masyarakat, 1(2).

Oktarosada, D., Annane, N., Yani, A. J. A., Gadingrejo, T. K., \& Pringsewu, K. (2021). Pengaruh Terapi Murotal Qur' an Surah Ar -Rahman Terhadap Penurunan Tekanan Darah Pada Penderita Hipertensi Di Wilayah Kerja Upt Puskesmas Bernung Kabupaten Pesawaran Tahun 2020. Jurnal Manajemen Pendidikan Islam Al Idarah, 6, 32-39.

Parman, Dwifitri, I., \& Amirullah, M. (2020). Pengaruh Terapi Murattal Surat Ar-Rahman Terhadap Tekanan Darah Lansia Penderita Hipertensi Di Puskesmas Simpang Kawat Kota Jambi Tahun 2018. 1(2), 66-75.

PPNI, Tim Pokja SDKI DPP. (2017). Standar Diagnosis Keperawatan. Dewan Pengurus Pusat Perawat Nasional Indonesia.

PPNI, Tim Pokja SIKI DPP. (2018). Standar Intervensi Keperawatan Indonesia. Dewan Pengurus Pusat Perawat Nasional Indonesia.

Ratnasari, Z. F. dan D. (2018). Patofisiologi Keperawatan. Manggu Makmur Tanjung Lestari.

Riskesdas. (2018). Laporan Nasional Riset Kesehatan Dasar. Kementerian Kesehatan RI, 1-582.

Sasmalinda, L. (2013). Faktor-faktor Yang Mempengaruhi Perubahan Tekanan Darah Pasien di Puskesmas Malalo Batipuh Selatan dengan Menggunakan Regresi Linier Berganda. UNP Journal of Mathematics, 2(1), 36-42.

Sinulingga, S. B. (2019). Pengkajian Keperawatan Dan Tahapannya Dalam Proses Keperawatan. https://doi.org/10.31219/osf.io/f7ecw

Susanti, N., Siregar, P. A., \& Falefi, R. (2020). Determinan Kejadian Hipertensi Masyarakat Pesisir Berdasarkan Kondisi Sosio Demografi dan Konsumsi Makan. Jurnal Ilmiah Kesehatan, 2(1), 43-52. https://doi.org/10.36590/jika.v2i1.52

Susilawati, A. (2019). Pengaruh Terapi Murottal Al-Qur'an Surah Ar-Rahman terhadap Penurunan Tekanan Darah pada Lansia Penderita Hipertensi di PSTW Budi Luhur Kota Jambi. Jurnal Akademika Baiturrahim Jambi, 8(2), 1-5. https://doi.org/10.36565/jabj.v8i2.5

Widia, L. (2015). Buku Saku Anatomi \& Fisiologi Tubuh Manusia.

Widyatama, H. G., Kusumaningrum, D., Widyasyifa, S. A., Rahmayanti, D., \& Gondoyuwono, H. (2020). Usia dan jumlah roko 